\section{Consumer Preferences for Tabletop Christmas Trees}

\author{
Bridget K. Behe, ${ }^{1}$ Rachel M. Walden, ${ }^{2}$ Marcus W. Duck, ${ }^{3}$ \\ Bert M. Cregg, ${ }^{4}$ and Kathleen M. Kelley ${ }^{5}$ \\ Department of Horticulture and Michigan Agricultural Experiment Station, \\ Michigan State University, Plant and Soil Sciences Building, East Lansing, \\ MI 48824-1325
}

\author{
R.D. Lineberger ${ }^{6}$ \\ Department of Horticultural Sciences, Texas A\&MUniversity, College Station, \\ TX 77843-2133
}

Additional index words. conifer, conjoint, Internet, marketing, survey

\begin{abstract}
An aging American population may be less willing than a younger population to install and remove a live, fresh-cut evergreen tree in their home for Christmas celebrations. An alternative to using traditional, large, fresh-cut or potted Christmas trees could be forcing these evergreen species in a small $(\approx 1-\mathrm{L})$ container that could be displayed on a tabletop. We initiated this study to determine consumer preferences and marketability for six evergreen tree species produced for tabletop display and used three decoration themes and three price points. We constructed a web-based survey in which 331 participants were compensated with a \$5 e-coupon for viewing 27 photographs of tabletop trees and providing preference and use information. The conjoint model accounted for $91.2 \%$ of the variance and showed that consumers valued tree species as the most important attribute (61\% of the tree value), with decoration color/theme the second most important feature $(27 \%)$ and, last, price $(12 \%)$. Black Hills spruce (Picea glauca var. densata (Moench) Voss) was the most preferred species overall, and red was the most preferred decoration theme. Logically, the lowest price point was the most preferred. However, price was the most important attribute for participants younger than 25 years. The importance of price decreased as participant age increased until age 60 , when price became a more important component. With a cost of production of $\$ 5.45$ and decoration and shipping estimated at an additional $\$ 4.00$, the product could be a profit generator priced at any of the tested price points (\$14.95 and above).
\end{abstract}

Fresh-cut, live Christmas trees are a popular holiday home decoration. About $31 \%$ of U.S. households displayed a fresh or live Christmas tree in $2000,49 \%$ had an artificial tree, $2 \%$ had both real and artificial trees, and $21 \%$ did not have a tree (National Christmas Tree Association, 2001) with a wholesale value of fresh, real trees at $\approx \$ 530$ million in 2001 (NASS, 2003). The 2003 International Fire Code revised a ban on fresh-cut Christmas trees from public buildings without automatic sprinkler systems, permitting them in private but not in public areas (Daggers, 2004).

Despite the current popularity of fresh trees, older consumers show less positive attitudes than younger consumers about bringing them into their homes (Florkowski and Lindstrom, 1995). Older consumers perceived that live trees were more difficult to bring in and out of the

\footnotetext{
Received for publication 19 Dec. 2003. Accepted for publication $11 \mathrm{Feb} .2004$. Research conducted at Michigan State University, East Lansing. Use of trade names does not imply endorsement of the products names or criticism of similar ones not named.

${ }^{1}$ Professor. To whom reprint requests should be sent; e-mail behe@msu.edu.

${ }^{2}$ Former informational statistical analyst.

${ }^{3}$ Instructor, former research associate.

${ }^{4}$ Assistant professor.

${ }^{5}$ Formerly postdoctoral assistant. Currently assistant professor, Department of Horticulture, The Pennsylvania State University.

${ }^{6}$ Professor..
}

home and created more of a mess than artificial trees. With $28 \%$ of Americans older than 60 years and another $30 \%$ between the ages of 40 and 59 years (Mitchell, 1998), concerns with regard to the use of fresh-cut Christmas trees indoors are likely to increase.

The average U.S. home size increased fom $1400 \mathrm{ft}^{2}$ in 1970 to $2100 \mathrm{ft}^{2}$ in 2000 (National Home Builders Association, 2002). With an increase in home size, some younger consumers may provide an additional market for those who want to purchase a second or third tree for their home. Additionally, a tabletop Christmas tree may present a profitable opportunity for the greenhouse operator because flowering potted plant production has not increased much beyond inflation (Behe et al., 2003).

We postulated that a traditional evergreen species, recognizable to many in the midwestern U.S. as a fresh-cut Christmas tree, grown in a small container (tabletop) might be marketable to consumers who either 1) perceived larger fresh-cut trees as too difficult to handle or 2) purchased more than one Christmas tree. Our objectives were to investigate Midwestern consumer preferences for six hardy (USDAZone 5) evergreen tree species grown in a container for use on a dining room or kitchen table.

\section{Materials and Methods}

To assess interest in tabletop Christmas trees, researchers conducted a conjoint-design,
Web-based survey in December 2001, which was approved by the university committee on research involving human subjects before implementation. Conjoint analysis allowed researchers to simultaneously investigate a number of product attributes and determine the importance of each attribute in the consumer's preference. Others used this method to determine consumer preferences for geraniums (Behe et al., 1999), outdoor ornamental plants (Townsley-Brascamp et al., 1995), rhododendrons (Gineo, 1990), potted chrysanthemums (Shafer and Kelly, 1986), fresh flower bunches (Robertson and Chatfield, 1982), and rose arrangements (Prince et al., 1980).

Researchers created a conjoint design using six tree species: Thuja occidentalis 'Emerald Beauty' L. (arborvitae), Picea glauca var. densata (Moench) Voss (black hills spruce), $P$. pungens Engelm. (colorado blue spruce), Abies concolor (Gord.) Lindl. ex Hildebr. (concolor fir), A. fraseri (Pursh) Poir. (fraser fir), and $P$. omorika (Panc.) Purk. (serbian spruce). The design also included three styles of decoration (undecorated, red color theme, or gold color theme) and three price points ( $\$ 14.95$, $\$ 19.95$, or \$24.95).

Scientists chose tree species, decoration, and price as factors that best described the range of attributes of a tabletop Christmas tree. We used an additive model in which the preference for each factor was added to form the overall preference for a particular tabletop Christmas tree. For each factor, we identified a hierarchical set of levels to investigate. We reduced the number of photographs required from 54 to 27 by using a partial factorial design, while maintaining factor orthogonality, which decreased potential participant fatigue. We asked participants to rate how much they liked each table-top tree on a 5-point Likert scale ( $1=$ like very little, $5=$ like very much). Conjoint analysis defines the overall consumer preference for a particular product, in this case a tabletop Christmas tree, as the sum of the part-worths, also defined as utilities, for each factor level. We accomplished Conjoint and other statistical analyses by using SPSS 10.0 (SPSS, Inc., Chicago, Ill.).

Internet access by adults at home or work is estimated to be 83.7 million in the United States (Mediamark Research, 2002) of a U.S. population estimated at 250 million, or $33 \%$. Further, Mediamark Reseach's data suggests about $42 \%$ of the total U.S. adult population (age $>18$ ) are regular Internet users (Mediamark Research, 2002). About $40 \%$ of women age 18 to 49 and $45 \%$ of men in the same age group had Internet access in 2000 (National Telecommunications and Information Association, 2004). Internet access by both genders declines after age 50. Compared to telephone and mail survey methods, we developed a Web-based survey to take advantage of a broad consumer sample, high and rapid response rate, decreased time and dollars associated with the elimination of hand-coding responses, and the ability to use color and high-quality images (Cobanoglu etal., 2001). Other researchers used Web-based surveys in horticulture and showed it was a feasible research technique in evaluating the benefits of 
children gardening (Waliczek, et al., 1999). The Web-based survey also helped to decrease errors associated with hand coding and researcher bias (McCullough, 1998). To increase response rate, a \$5 e-coupon was given to participants as an incentive (Cobanoglu et al., 2001).

The Internet survey was established on the Texas A\&M University Horticulture Department network Web server, Aggie Horticulture. We designed the survey to be answered voluntarily by persons who were age $>18$ and lived in the USDA classification of Midwestern states: Minnesota, Michigan, Ohio, Indiana, Iowa, Wisconsin, and Illinois. Survey Sampling (Fairfield, Conn.), a professional sampling company, randomly selected 5000 e-mail addresses used in the study from their ELITe database, which is composed of e-mail addresses collected through a variety of permission-based marketing sources and comprises more than 1 million U.S. consumers.

The survey contained a total of 55 questions. Besides being asked to rate the 27 digital images of tabletop Christmas trees, we asked participants about their past Christmas tree purchases, preferences for artificial and live Christmas trees, and demographic information.

\section{Results and Discussion}

The sample of 331 participants was composed of $84.3 \%$ females and $15.7 \%$ males, consistent with the profile of consumers who purchase horticultural products (National Gardening Association, 2001). Participant age ranged from 18 to 76 years, with a mean of 43 years. More than half of the participants had some college or technical school training $(54.3 \%)$, and $42.9 \%$ were only high school graduates. More participants were in the yearly household income categories of $\$ 20,000$ to $\$ 39,999(36.1 \%), \$ 40,000$ to $\$ 69,999(23.1 \%)$, or more than $\$ 70,000(20.1 \%)$. More than half of the participants (54\%) had two people living at home who were older than 18 years. About half did not have any persons younger than 18 years living at home, but $20 \%$ had one person younger than 18 years in the household, and $15.4 \%$ of the respondents had more than two persons younger than 18 years in the household. Participants lived in various parts of the Midwest region: $25.9 \%$ were from Ohio; $16.8 \%$, from Indiana; $16.5 \%$, from Michigan; 5.3\%, from Iowa; $12.5 \%$, from Wisconsin; $7.5 \%$, from Minnesota; and $15.6 \%$, from Illinois.
Half of the participants had purchased a tabletop Christmas tree in the past (51\%), and $11 \%$ had purchased a Norfolk Island pine. Most people $(66 \%)$ who purchased Norfolk Island pine preferred it to a tabletop Christmas tree (Araucaria heterophylla (Salisb.) Franco). When asked preference questions using a 5-point hedonic scale (strongly disagree to strongly agree), most people preferred live Christmas trees over artificial trees (Table 1). The participants liked fresh or live trees better than artificial trees (42\%), and more than half acknowledged that they were harder to take home $(69 \%)$, messier $(76 \%)$, and more of a fire hazard (55\%). However, less than half agreed that fresh or live Christmas trees were harder to take down $(41 \%)$, more expensive $(39 \%)$, or better than artificial trees (42\%).

The conjoint model accounted for $91.2 \%$ of of the variation in consumer preferences. The species was the most important attribute (accounting for $61 \%$ of the variance in consumer preferences), with decoration color/theme the second most important feature $(27 \%)$, followed by price $(12 \%)$. Black hills spruce was the most preferred species overall and was also the most preferred species when preferences were examined by age group (Table 2 ). Consumers preferred the red-theme decoration and, logically, the lowest price point.

The tree most respondents selected as their favorite was the black hills spruce with red decoration priced at $\$ 19.95$ (Fig. 1). The least favorite tree was the undecorated arborvitae priced at \$24.95 (Fig. 2). Most participants reported that they would consider purchasbe more likely to purchase the tree if it were already decorated. Of the respondents, $87 \%$ planned on including a Christmas tree in their the variance, indicating it accounted for most ing their favorite tree $(74 \%)$, and $55 \%$ would

home that year. Of those who were including a Christmas tree in their home, $27 \%$ were using live or fresh-cut trees and $73 \%$ were using artificial trees. The use of artificial trees was $12 \%$ higher than in the national survey by the Christmas Tree Association in 2000 (National Christmas Tree Association, 2001).

We divided consumers into four age groups and discovered that their preferences for price point varied. Price was the most important attribute for participants aged 18 to 25 years. The importance of price decreased as participant age increased until age 60 , when price again became more a more important component (Table 3).

\section{Cost of Production Analysis}

Since there was a general preference for the red decorated black hills spruce as a table-top Christmas tree, the next question researchers asked was one of profitable production. Could the most-preferred tabletop tree be produced economically with some potential profit for a grower? We investigated cost of production to force 1000 Black Hills spruce (P. glauca var. densata). We obtained prices for inputs from a 2003 published national wholesale growersupply catalog (Hummert International, Earth City, Mo.). Nearly every commercial grower in the U.S. would negotiate a lower price compared to the published catalog price. The negotiated lower price would vary, depending on economies of scale in purchasing and other factors. Thus, the researchers perceived the published catalog price as an ultra-conservative one. If a profit could be demonstrated using a published catalog price for costs of production, the likelihood of generating profit using a lower negotiated price would be extremely high.

Using protocols from production research

Table 1. Consumer responses to questions regarding their preferences for live tabletop Christmas trees.

\begin{tabular}{lccc}
\hline & & $\begin{array}{c}\text { For each statement, } \\
\text { the percentage of } \\
\text { consumers who }\end{array}$ \\
\cline { 2 - 4 } "Live Christmas trees are . ."” & Agree & Are neutral & Disagree \\
\hline Better than artificial trees & 42.3 & 32.4 & 25.3 \\
Harder to carry home than artificial trees & 69.1 & 18.8 & 12.0 \\
Harder to decorate than artificial trees & 18.2 & 34.0 & 47.8 \\
Messy & 75.6 & 14.8 & 9.6 \\
More expensive than artificial trees & 38.9 & 32.4 & 28.7 \\
More dangerous because they can catch on fire & 54.6 & 28.4 & 17.0 \\
Better than artificial because they are natural & 42.9 & 38.6 & 18.5 \\
Harder to take down than artificial trees & 41.4 & 27.8 & 30.9 \\
\hline
\end{tabular}

Table 2. Consumer preferences for tree species overall and by age group.

\begin{tabular}{|c|c|c|c|c|c|}
\hline \multirow{3}{*}{$\begin{array}{l}\text { Tree } \\
\text { species }\end{array}$} & \multicolumn{5}{|c|}{ Age of participants (years) } \\
\hline & Overall $^{\mathrm{z}}$ & $<26^{y}$ & $26-45^{x}$ & $46-60^{\mathrm{w}}$ & $>60^{\mathrm{v}}$ \\
\hline & $n=324$ & $n=31$ & $n=166$ & $n=106$ & $n=21$ \\
\hline Thuja occidentalis 'Emerald beauty' (arborvitae) & -0.0566 & -0.3343 & -0.0213 & 0.0027 & -0.2389 \\
\hline Picea glauca var. densata (black hills spruce) & 0.9025 & 0.5623 & 0.8754 & 0.9962 & 1.1278 \\
\hline Picea pungens (colorado blue spruce) & -0.7588 & -0.6159 & -0.7755 & -0.8064 & -0.5889 \\
\hline Abies concolor (concolor fir) & -0.2717 & 0.022 & -0.3019 & -0.363 & 0.0111 \\
\hline Abies fraseri (fraser fir) & -0.2158 & 0.1025 & -0.2111 & -0.2853 & -0.3556 \\
\hline Picea omorika (serbian spruce) & 0.4004 & 0.2634 & 0.4344 & 0.4558 & 0.0444 \\
\hline
\end{tabular}

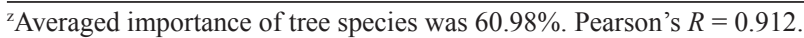

y Averaged importance of tree species was $57.10 \%$. Pearson's $R=0.883$.

${ }^{x}$ Averaged importance of tree species was 57.05\%. Pearson's $R=0.905$.

${ }^{\text {w} A v e r a g e d ~ i m p o r t a n c e ~ o f ~ t r e e ~ s p e c i e s ~ w a s ~} 66.71 \%$. Pearson's $R=0.908$.

v'Averaged importance of tree species was $66.59 \%$. Pearson's $R=0.952$. 


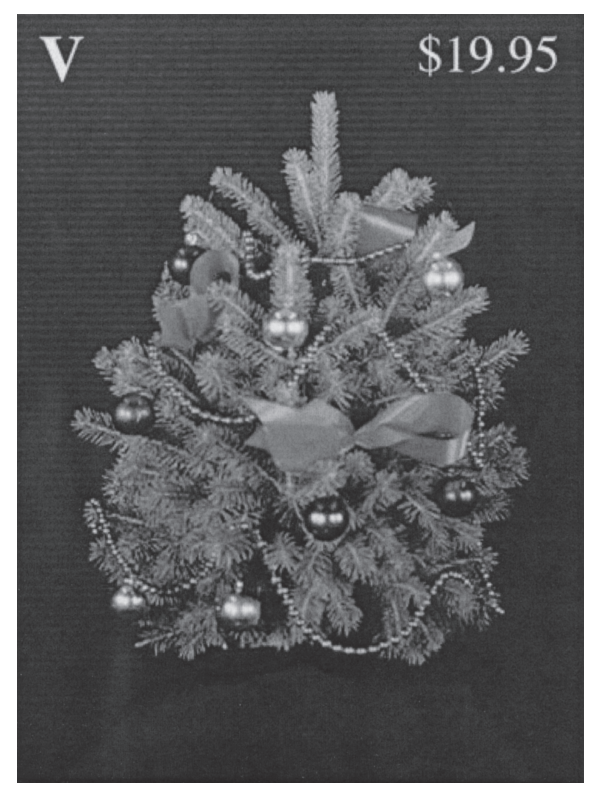

(Duck, 2002), we developed the cost to force or flush trees in Michigan for market in late November (Table 4). Cost of production was estimated at $\$ 5.45$, using an indirect cost figure from Uva and Richards (2003). Decoration and shipping costs could be estimated from $\$ 1.00$ to $\$ 2.00$. Shipping charge was in direct proportion to the distance shipped, so it would vary with the distance from producer to retailer. If a high estimate for decoration (\$2.00) was combined with a high estimate for shipping

Table 3. Price importance by participant age group. ${ }^{z}$

\begin{tabular}{lc}
\hline $\begin{array}{l}\text { Participant } \\
\text { age (years) }\end{array}$ & $\begin{array}{c}\text { Importance } \\
\text { score }\end{array}$ \\
\hline $18-25$ & 15.4 \\
$26-45$ & 13.3 \\
$46-60$ & 9.4 \\
$>61$ & 14.4 \\
\hline
\end{tabular}

${ }^{2}$ Conjoint analysis does not have an option to discern statistical differences in importance scores, such as would be calculated with a $\chi^{2}$ test.

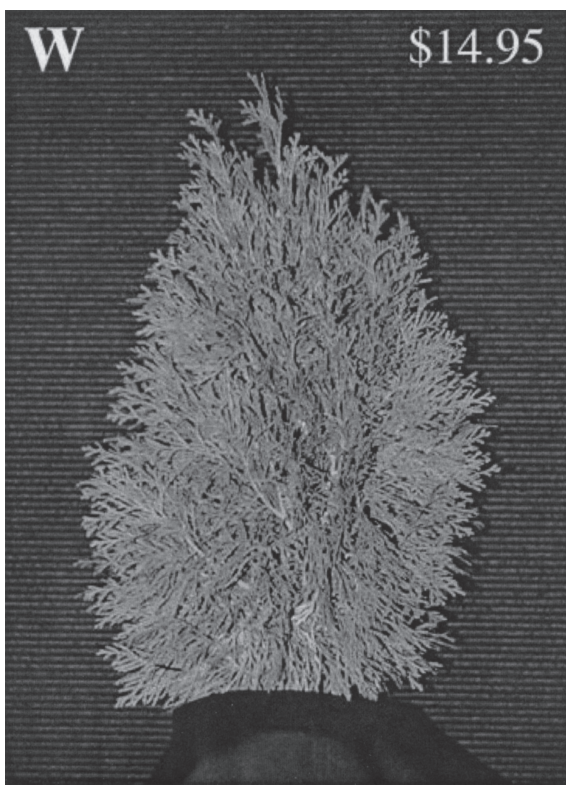

(\$2.00), we identified total cost of production as $\$ 9.45$. If we assumed a total cost of $\$ 9.45$ including shipping and decoration, the product could be profitably priced at any of the price points tested. A 50\% markup on-cost would produce a price point of $\$ 14.17$ close to the lowest price point tested. A 100\% markup on cost would produce a price point of $\$ 18.90$, close to the mid price point tested. Thus, we concluded that, using conservative cost estimates and a typically-used markup on cost, black hills spruce can be marketed profitably as a table-top Christmas tree.

\section{Conclusion}

Many consumers still enjoy the beauty and symbolism of a fresh Christmas tree in their home. In addition to - or as a substitute for-a fresh-cut tree, there appears to be significant consumer acceptance of tabletop Christmas trees. More traditional tree species (like the

Table 4. Cost of production for 1000 black hills spruce (Picea glauca var. densata) for market and use as tabletop Christmas trees.

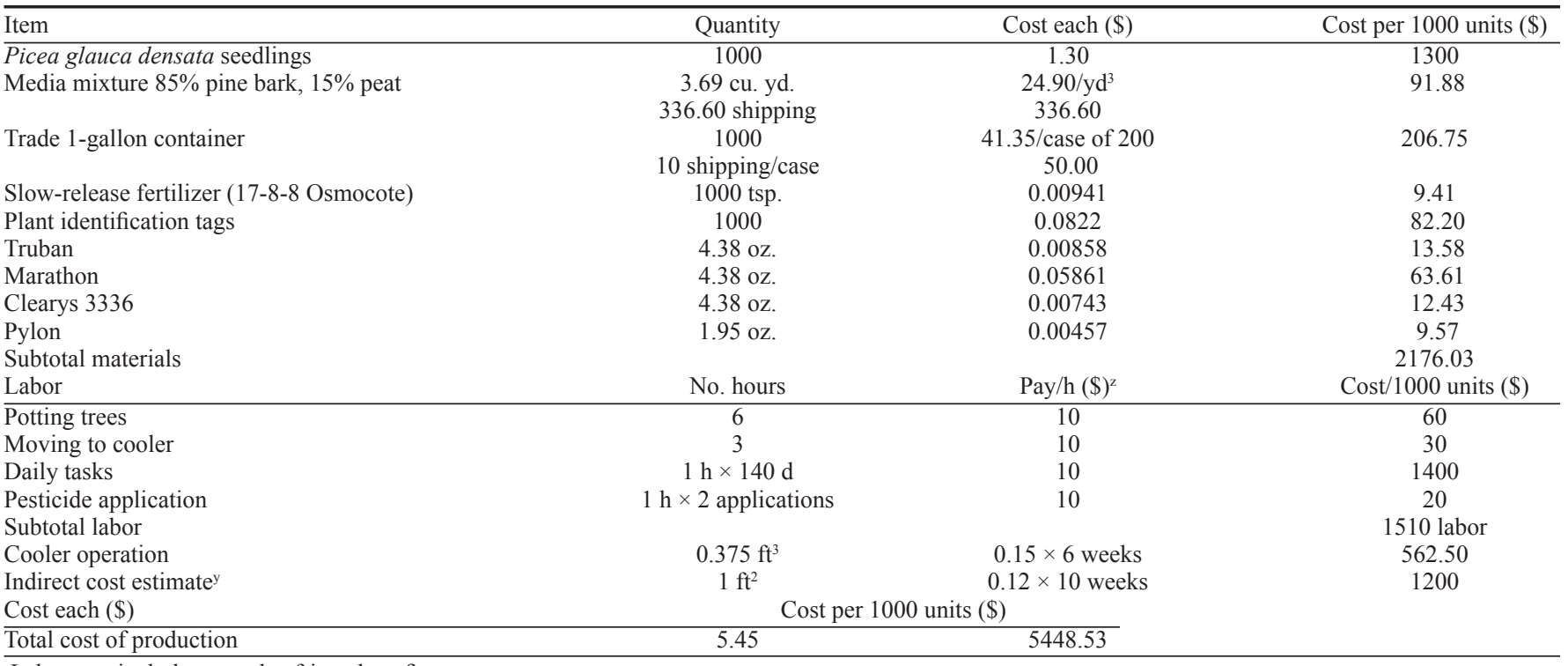

${ }^{2}$ Labor rate includes pay plus fringe benefits.

'Indirect cost estimate includes all other overhead charged to the crop on a square foot basis using the most conservative figure from Uva and Richards (2003). 
black hills spruce) will have wider acceptance than less traditional species like arborvitae. Trees should be marketed with decorations because they are preferred to undecorated trees. Although consumers naturally prefer lower prices to higher ones, there may be some potential to pricing decorated trees moderately and reaping a better profit. Conservative estimates for cost of production showed plants could be produced for $\$ 9.45$ and marketed at a markup of at least $50 \%$ and generate profits for the grower.

\section{Literature Cited}

Behe, B., R. Nelson, S. Barton, C. Hall, C.D. Safley, and S. Turner. 1999. Consumer preferences for geranium flower color, leaf variegation, and price. HortScience 34:740-742.

Behe, B.K., E.C. Moore, A.C. Cameron, and F.S. Carter. 2003. Consumer perceptions for and uses and perceptions of selected flowering perennial plants. HortScience 38(3):460-464.

Cobanoglu, C., B. Warde, and P.J. Moreo. 2001. A comparison of mail, fax, and Web-survey methods. Intl. J. Mkt. Res. 43:441-452.

Daggers, S. 2004. International Code Council. 29 Sept. 2004. http://www.iccsafe.org/news/ nr/031203xmastrees.html.

Duck, M.W. 2002. Developing production systems for tabletop Christmas trees. MS thesis. Mich. State Univ., East Lansing.

Florkowski, W.J. and O.M. Lindstrom. 1995. Consumer characteristics associated with perceptions of live Christmas trees. J. Environ. Hort. 13:15-18.

Gineo, W.M. 1990. A conjoint/logit analysis of nursery stock purchases. N.E. J. Agr. Res. Econ. 19:49-58.

Mediamark Research, Inc. 64.2 million U.S. adults regular Internet users. 15 Apr. 2002. http://www. internetindicators.com/facts $1 . \mathrm{html}$.

McCullough, R. 1998. Web-based market research: Dawning of a new age. Direct Mkt. 61:36-38.

Mitchell, S. 1998. American generations: Who they are, how they live, what they think. New Strategist Publ., Ithaca, N.Y.

National Agricultural Statistics Service, 2003. National Christmas Tree Association. Industry statistics, 2001. 28 Aug. 2003. http://www. realchristmastrees.org/industry.html.

National Christmas Tree Association. Industry statistics, 2001. 1 Apr. 2002. http://www.realchristmastrees.org/industry.html.

National Gardening Association. 2002. $2001 \mathrm{Na}-$ tional Gardening Survey. Burlington, Vt.

National Home Builders Association. 2002. Fact sheet. 13 Nov. 2002.http://www.nahb.com/facts/ nextdecadeforecast.pdf.

National Telecommunications and Information Administration. 2004. Fact sheet. 28 June 2004. http://www.ntia.doc.gov/ntiahome/fttn00/chartII-6.htm.

Prince, T.L., J.L. Robertson, and L.H. Chatfield. 1980. Factors affecting the marketability of roses. J. Amer. Soc. Hort. Sci. 105:388-393.

Robertson, J.L. and L.H. Chatfield. 1982. Fresh flower merchandising in loose bunches. HortScience 17:593-595.

Shafer, B.S. and J.W. Kelly. 1986. The influence of cultivar, price, longevity on consumer preferences for potted chrysanthemums. HortScience 21:1412-1413.

Townsley-Brascamp, W., N.E. Marr, E. Matsuo, and P.D. Relf. 1995. Evaluation and analysis of consumer preferences for outdoor ornamental plants. Acta Hort. 391:199-206.

Uva, Wen-fei and Steve Richards. 2003. New York greenhouse business summary and financial analysis, derived from 2001 financial records. 4 Aug. 2004. http://aem.cornell.edu/outreach/ extensionpdf/eb0312.pdf.

Waliczek, T., J.C. Bradley, R.D. Lineberger, and J.M. Zajicek. 1999. Using a Web-based survey to research the benefits of children gardening. HortTechnology 10:71-76. 